\title{
Preliminary Evaluation of the Physicochemical and Antiplasmodial Properties of Syrup Formulations Containing the Aqueous Root Extract of Nauclea latifolia (Rubiaceae)
}

\author{
Olubunmi J. Olayemi ${ }^{1 *}$, Lucy B. John-Africa ${ }^{2}$, Chinwe B. Chikwendu ${ }^{1}$, Christianah Y. Isimi ${ }^{1}$ \\ ${ }^{1}$ Department of Pharmaceutical Technology and Raw Materials Development, National Institute for Pharmaceutical Research and Development, Abuja, \\ Nigeria \\ ${ }^{2}$ Department of Pharmacology and Toxicology, National Institute for Pharmaceutical Research and Development, Abuja, Nigeria
}

DOI: $10.36348 /$ sjmps.2020.v06i08.005

| Received: 05.08.2020 | Accepted: 13.08.2020 | Published: 22.08.2020

*Corresponding author: Olubunmi J. Olayemi

\section{Abstract}

Malaria is a life-threatening disease with high mortality and prevalence especially in children under the age of 5 . Herbal remedies like Nauclea latifolia have been used and found to be effective in the treatment of malaria. However, presentations like decoctions, liquid extracts are not suitable particularly for children. Therefore, in this study, syrup formulations of the dried aqueous root extract of Nauclea latifolia (AREL) were developed using honey, simple syrup BP and water as vehicle in the presence and absence of a sweetener, thickener and preservatives. Organoleptic and physicochemical properties such as odor, color, taste, homogeneity, $\mathrm{pH}$ and density were evaluated. Stability of the syrups at room temperature, in the refrigerator and at accelerated temperature was also evaluated. In vivo anti-plasmodial activity of optimized syrup formulation was investigated according to standardized methods. Results show the syrups were brown to amber in color, homogenous and had sweet to bitter taste. The $\mathrm{pH}$ of the syrups were between 4.45 and 5.78 , flow rate was between 0.00 and $2.17 \mathrm{~g} / \mathrm{sec}$. Density was between 1.24 and $1.41 \mathrm{~g} / \mathrm{mL}$; syrups containing honey were non-flowing while those formulated with simple syrup were more free-flowing. In vivo studies show that the optimized syrup formulation possess ability to inhibit parasitemia. No observable changes were noticed after the period of storage. This study shows that the development of the dried aqueous root extract of Nauclea latifolia into syrups as a standardized dosage form capable of inhibiting parasitemia could be explored.

Keywords: Nauclea latifolia, dried root extract, syrup, honey, simple syrup, physicochemical evaluation.

Copyright @ 2020: This is an open-access article distributed under the terms of the Creative Commons Attribution license which permits unrestricted use, distribution, and reproduction in any medium for non-commercial use (NonCommercial, or CC-BY-NC) provided the original author and source are credited.

\section{INTRODUCTION}

Malaria is a major life-threatening disease with high rates of prevalence and mortality. There are about 200 - 250 million cases reported annually resulting in about $1-2$ million deaths, $90 \%$ of which occur in Africa with Nigeria accounting for a quarter of all malaria cases in Africa [1]. Malaria is holoendemic in Nigeria; it is the most common cause of hospital visits in all age groups but particularly devastating to children under 5 years [2]. Early diagnosis and treatment with recommended therapies reduce the risks of complication, rate of transmission and death. However, resistance to available antimalarial agents has become a recurring problem resulting to various challenges in the management of malaria especially in areas where multi drug resistance is prevalent. This has consequently heightened the interest in the search for novel alternative treatments for malaria and especially the development of herbal medicines [3].
Herbal plants have been in use for the treatment of malaria for many years and are still being used in healthcare worldwide. About $80 \%$ of the population in developing countries depend on herbal medicines for their basic health needs [4] because they are purported to be as effective as conventional medicines while being cheap and relatively safe.

Nauclea latifolia; family; Rubiaceae, is one of those medicinal plants used traditionally in the treatment of malaria [5]. It is a deciduous flowering plant that is readily available in West Africa; its various parts have diverse applications locally [6]. The antimalarial beliefs of Nauclea latifolia has been investigated and reported to be effective in its claim by many researchers. The crude root extract of Nauclea latifolia has been observed to cure Plasmodium berghei infected rats [7] and mice. Its antioxidant property has been postulated to be one of the mechanisms 
responsible for its anti-plasmodial action [8]. Some other studies showed that the aqueous extract of Nauclea latifolia possess dose-dependent chemosuppressive anti-plasmodial activities [9,10]. Comparative studies have shown that the aqueous root extract of Nauclea latifolia possesses better chemosuppressive activity than some other plant extracts like Vernonia spps [11], Cissampelos mucronata [12], Parkia biglobosa [13] and Clerodendrum myricoides [14]. The ethanol extract of Nauclea latifolia was also observed to clear parasitemia in laboratory mice as effectively as Artemether/Lumefantrine $\left(\right.$ Coartem ${ }^{\circledR}$ ) when used at the same concentration [15]. This study also demonstrated that the extract offered moderate neuro-protection to the hippocampus of Plasmodium berghei infected mice.

Herbal medicines customarily prepared by maceration, decoction or infusion are usually unpalatable to taste and non-aesthetic. This could influence patient's compliance to therapy therefore, it is necessary to prepare these herbal extracts into suitable dosage forms like syrups. Syrups are viscous, sweettasting aqueous preparations containing high concentration of sucrose. They are easy to administer, able to mask unpleasant taste and provide soothing effect on irritated tissues [16]. They are usually formulated for paediatrics, geriatrics and those who find it difficult to swallow due to some physiological conditions.

The purpose of this study is to formulate syrups containing the dried aqueous root extract of Nauclea latifolia (AREL) using different vehicles, evaluate their physicochemical properties as well as antiplasmodial activity.

\section{Materials}

Dried aqueous root extract of Nauclea latifola obtained from the NIPRD laboratory, methyl paraben and propyl paraben (Tianjin Zhongxin Chemtech Co., Ltd, China), sugar and honey sourced from the National Institute for Pharmaceutical Research and Development, Laboratory, Nigeria.

\section{Methods}

Collection, Identification and Preparation of the dried aqueous root extract of Nauclea latifolia

The roots of the plant Nauclea latifolia were obtained from the botanical garden of the National Institute for Pharmaceutical Research and Development (NIPRD), Abuja, Nigeria. Plant identification was done by the institute's taxonomist, Muazzam Ibrahim and a specimen stored in the Institute's herbarium with voucher specimen reference No 4251. The root bark was washed and dried in a drying cabinet and pulverized using a mechanical grinder. The powdered material was extracted using distilled water by hot maceration for $24 \mathrm{~h}$, then filtered through a muslin cloth and freeze-dried using LYOVAC, GT2 (Germany). The freeze-dried extract was then stored in an air tight container and stored in a desiccator.

\section{Preparation of the herbal syrups}

Honey, simple syrup and distilled water were used as vehicle for the preparation of the herbal formulation according to the formula in Table-1 below. Appropriately weighed quantities of AREL were placed in a mortar and where required, the preservatives (methyl paraben and propyl paraben) and sweetener were mixed with the extract. A portion of the vehicle was added to the content of the mortar and triturated together to make a smooth paste. The remaining volume of vehicle was incorporated into the mortar and triturated until a homogenous mixture was obtained which was transferred into a bottle, labelled appropriately and stored until further use.

\section{Materials ANd Methods}

Table-1: Composition for the preparation of syrups containing AREL

\begin{tabular}{|r|r|r|r|r|r|r|}
\hline Ingredients/Batch & H1 & H2 & H3 & S1 & S2 & S3 \\
\hline AREL (g) & 0.9 & 0.9 & 0.9 & 0.9 & 0.9 & 0.9 \\
\hline Methyl paraben (g) & - & 0.06 & 0.06 & - & 0.06 & 0.06 \\
\hline Propyl paraben (g) & - & 0.03 & 0.03 & - & 0.03 & 0.03 \\
\hline Sweetener (g) & - & - & 3 & - & - & 3 \\
\hline Honey (mL) & 60 & 45 & 45 & - & - & - \\
\hline Syrup (mL) & - & - & - & 60 & 45 & 45 \\
\hline Water (mL) to & - & 60 & 60 & - & 60 & 60 \\
\hline
\end{tabular}

Key: $A R E L=$ Aqueous root extract of Nauclea latifolia; H1 and S1 = preparations containing only AREL in honey and AREL in simple syrup respectively, $H 2$ and $S 2$ = preparations containing AREL, preservatives and honey in water and simple syrup respectively, $\mathrm{H} 3$ and $\mathrm{S} 3$ = preparations containing AREL, preservatives, sweetener, honey in water and simple syrup respectively. 
Physicochemical evaluation of syrup formulations containing AREL

\section{Physical evaluation}

The color, odor and taste of the syrups were evaluated.

\section{Chemical evaluation \\ Determination of specific gravity at room temperature \\ The pycnometer was used to determine} specific gravity $(\mathrm{g} / \mathrm{mL})$ of the syrups. The weight of the empty pycnometer and its weight when filled with water were recorded as $\mathrm{W}_{1}$ and $\mathrm{W}_{2}$ respectively. The weight of the syrup in the pycnometer and the weight of the pycnometer filled with equal volume of water were recorded as $\mathrm{W}_{3}$ and $\mathrm{W}_{4}$. Specific gravity was computed using the formula below;

$$
\text { Specific gravity }=W 3-W 1 / W 4-W 1
$$

\section{Determination of density of syrup}

The method of Tewari and Kumar [27], was adopted; the empty bottle of known volume was weighed $\left(\mathrm{W}_{\mathrm{v}}\right)$ and then filled with syrup and weighed again $\left(\mathrm{W}_{\mathrm{s}}\right)$. The difference between the weight of the empty bottle and the bottle containing the syrup was recorded $(\mathrm{Wx})$ and density was calculated using the given formula;

$$
\text { Density }=W x / W v
$$

\section{Determination of $\mathbf{p H}$}

The $\mathrm{pH}$ of the syrups was determined using the digital $\mathrm{pH}$ meter (Denver $\mathrm{pH}$ meter). Three determinations were recorded and the average calculated.

\section{Determination of flow rate}

This was determined using the funnel method.

\section{Evaluation of Syrup stability}

The prepared syrups were stored at room temperature, in the refrigerator and at accelerated temperature $\left(40{ }^{\circ} \mathrm{C}\right)$ for 30 days and assessed visually for presence/absence of growth or crystals.

\section{Animals and ethics statement}

Swiss Albino mice $(24-28 \mathrm{~g})$ of either sex were used for the study. These were obtained from the Animal Facility Centre (AFC) of the National Institute for Pharmaceutical Research and Development (NIPRD) Idu, Abuja. The animals were housed in plastic cages and maintained under ambient laboratory conditions. They were fed on standard rodent diet with free access to tap water. The study was carried out following approval obtained from the Institutional Animal Care and Ethics committee (NIPRD/05.03.056).

\section{In vivo anti-plasmodial activity}

This was determined by an established method [17]. The curative test was carried out in mice infected with chloroquine-sensitive Plasmodium berghei (NK65). Donor mouse previously infected with Plasmodium berghei was sacrificed by diethylether inhalation. The thoracic region was opened and blood was collected by cardiac puncture into heparinized tube. Normal saline was used to dilute the blood to achieve a concentration of $1 \times 10^{7}$ parasitized red blood cells which was given intraperitoneally to each mouse on Day 0 . After $72 \mathrm{~h}$ (Day 3), blood obtained from the tail of the mice was used to prepare thin blood films which was used to determine the level of parasitemia.

The mice were subsequently randomized into 5 groups of 6 mice each; mice in group 1 which served as negative control received $\mathrm{SV}$; the vehicle of the formulation $(10 \mathrm{~mL} / \mathrm{kg} /$ day $)$, groups 2 and 3 were administered 200 and $400 \mathrm{mg} / \mathrm{kg} /$ day of formulation S3. Group 4 which is the positive control, was treated with chloroquine $(5 \mathrm{mg} / \mathrm{kg} /$ day $)$ while group 5 was the untreated, uninfected group.

Treatment was administered once daily in a single dose for five (5) days i.e. Day 3 - Day 7. Thin blood smears were prepared at 2-day intervals then $24 \mathrm{~h}$ after the last treatment, blood was obtained from the tail of the mice for hematological analysis carried out using Wincom YNH70213-Diff hematology analyzer. The slides were Geimsa stained and the number of parasitized red blood cells and total number of cells were counted in randomly selected fields $(n=10)$. Mortality was monitored over a 30-day period; percentage parasitemia, percentage of suppression and mean survival time was calculated using the formulae below;

$$
\begin{aligned}
& \text { Parasitemia }(\%)=\frac{\text { total number of parasitized } R B C s}{\text { total number of } R B C S} \times 100 \\
& \text { Suppression }(\%)=\frac{\text { parasitemia in negative control }- \text { parasitemia in treated group }}{\text { parasitemia in negative control }} \times 100 \ldots \ldots . \\
& \text { Mean survival time }=\frac{\text { total number of days of survival of all mice in the group }}{\text { total number of mice in that group }}
\end{aligned}
$$




\section{STATISTICAl AnAlysis}

Values are presented as Mean \pm SEM and analyzed using Graph Pad Prism V 6.01. Comparison were made between control and treatment group using One-way Analysis of variance (ANOVA). Followed by Dunnet's multiple comparison test. Level of significance was set at $\mathrm{p}<0.05$.

\section{RESULTS AND DISCUSSION}

\section{Physical properties of syrups containing AREL}

The physical properties of the formulated syrups are presented in Table (2). All the syrups were brown to amber in color, they were found to be odourless except those prepared with honey $(\mathrm{H} 1, \mathrm{H} 2$ and H3) which had a characteristic odor. Syrups prepared with honey $(\mathrm{H} 1, \mathrm{H} 2, \mathrm{H} 3)$ were sweet to taste while those prepared with syrup (S1, S2 and S3) even though contained a sweetener were bitter. This is attributed to the unpleasant taste of the extract (AREL) due to the presence of alkaloids which is known to be bitter-tasting [18, 19]. Honey was found to mask the bitter taste of the extract, resulting in the sweet-tasting syrups.

The $\mathrm{pH}$ of the syrups were observed to be between 4.45 and 5.78. Syrups prepared with honey as the vehicle (H1) and those containing honey with water as vehicle ( $\mathrm{H} 2$ and $\mathrm{H} 3$ ) were found to have similar $\mathrm{pH}$ with honey alone (4.42). On the other hand, the $\mathrm{pH}$ of formulations S1, S2 and S3 prepared with simple syrup as vehicle and its combination with water were 5.50, $5.63,5.78$ respectively which was lower than the $\mathrm{pH}$ of simple syrup alone (6.63). Although the presence of AREL is seen to lower the $\mathrm{pH}$ of the preparations, the influence was not remarkable.

Density of the syrups was observed to be between 1.24 and $1.41 \mathrm{mg} / \mathrm{mL}$. Preparations containing honey as vehicle (H1) and simple syrup as vehicle (S1) were the densest although they were also similar (1.41 and 1.40 respectively). This was followed by those prepared with the combination of simple syrup and water ( $\mathrm{H} 2$ and $\mathrm{H} 3)$ which also had similar densities (1.31) while S2 and S3 which also had similar densities (1.24 and 1.28 respectively) were the least dense.

Table-2: Organoleptic and Physicochemical properties of formulated syrups containing AREL

\begin{tabular}{|r|r|r|r|r|r|r|}
\hline Parameters/ Batch & H1 & H2 & H3 & S1 & S2 & S3 \\
\hline Color & Brown & Brown & Brown & Amber & Amber & Amber \\
\hline Odor & Honey & Honey & Honey & Odorless & Odorless & Odorless \\
\hline Taste & Sweet & Sweet & Sweet & Bitter & Bitter & Slightly bitter \\
\hline $\mathrm{pH}$ & 4.48 & 4.45 & 4.63 & 5.50 & 5.63 & 5.78 \\
\hline Flow rate $(\mathrm{g} / \mathrm{sec})$ & $0.00 \pm 2.00$ & $0.25 \pm 2.00$ & $0.01 \pm 2.52$ & $0.45 \pm 1.00$ & $1.25 \pm 1.00$ & $2.17 \pm 0.58$ \\
\hline Density $(\mathrm{g} / \mathrm{mL})$ & $1.40 \pm 1.00$ & $1.31 \pm 1.16$ & $1.31 \pm 1.51$ & $1.41 \pm 2.00$ & $1.24 \pm 1.00$ & $1.28 \pm 0.56$ \\
\hline
\end{tabular}

Flow rate measures how quickly fluid would move from one point to the other or through an orifice. The time taken for a viscous or dense fluid to flow out or through an opening would be longer than that of a less viscous fluid. This suggests that formulations S2 and S3 would be more easily dispensed from their final container than the other syrup formulations and this is important to ensure patient compliance and product efficacy. Table-2 shows that syrups prepared with honey and its combination with water had very poor flow which corresponds to the density of the preparations.

Table-3: Organoleptic evaluation of formulated syrups containing AREL after storage at different temperatures for 30 days

\begin{tabular}{|r|l|l|l|l|r|r|r|}
\hline Batches & H1 & H2 & H3 & S1 & S2 & S3 \\
\hline \multicolumn{7}{|c|}{} & $\mathbf{4}^{\mathbf{0}} \mathbf{C}$ \\
\hline Color & No change & No change & No change & No change & No change & No change \\
\hline Odor & No change & No change & No change & No change & No change & No change \\
\hline Growth & No growth & No growth & No growth & No growth & No growth & No growth \\
\hline \multicolumn{7}{|c|}{ Room Temperature } \\
\hline Color & No change & No change & No change & No change & No change & No change \\
\hline Odor & No change & No change & No change & No change & No change & No change \\
\hline Growth & No growth & No growth & No growth & No growth & No growth & No growth \\
\hline \multicolumn{7}{|c|}{} \\
\hline Color & No change & No change & No change & No change & No change & No change \\
\hline Odor & No change & No change & No change & No change & No change & No change \\
\hline Growth & No growth & No growth & No growth & No growth & No growth & No growth \\
\hline
\end{tabular}


Stability studies of the prepared syrups as presented in Table (3) shows that all the syrups retained their physical properties (colour, odour, presence/absence of growth) under the different storage conditions. Honey used in formulations $\mathrm{H} 1, \mathrm{H} 2$ and $\mathrm{H} 3$ possesses broad spectrum antimicrobial property [20] and maybe be responsible for preserving the syrups under storage. Although simple syrup on the other hand is known to be bacteriostatic, the presence of preservatives (methyl paraben and propyl paraben) in formulations S1, S2 and S3 could account for the stability of the syrups observed.

Based on the $\mathrm{pH}$, better flow rate and density of the formulated syrups, formulation S3 containing AREL prepared with combination of simple syrup and water and a sweetener was selected for the in vivo study.

\section{In vivo anti-plasmodial activity}

The anti-plasmodial activity of the formulated syrup was determined using the curative in vivo antiplasmodial assay. There is a rise in the use of plant extracts for the treatment of diseases in man with these extracts being formulated into suitable oral dosage forms that have shown significant pharmacological actions [21, 22]. Extracts obtained from the plant have been reported to possess antimalarial properties [23]. Administration of the formulated syrup to mice with established infection showed a decrease in the level of parasitemia after five days of treatment (D7). The antiplasmodial action of syrup formulation (S3) was found to be dose-dependent evident from the parasite clearance as shown in Table (4) with significant reduction $(\mathrm{P}<0.05)$ at $400 \mathrm{mg} / \mathrm{kg}$. Reduction in parasitemia was also observed with the group treated with chloroquine at $5 \mathrm{mg} / \mathrm{kg}$.

Table-4: Anti-plasmodial effect of syrups containing AREL and survival time in mice infected with Plasmodium berghei

\begin{tabular}{|r|r|r|r|}
\hline Treatment & Mean \% parasitemia (D7) & \% Suppression & Mean survival time (Days) \\
\hline Control SV & $3.27 \pm 0.83$ & - & $8.67 \pm 0.67$ \\
\hline S3 $200 \mathrm{mg} / \mathrm{kg}$ & $2.34 \pm 0.85^{\mathrm{a}}$ & 28.44 & $10.00 \pm 0.55$ \\
\hline S3 $400 \mathrm{mg} / \mathrm{kg}$ & $1.88 \pm 0.12^{\mathrm{c}}$ & 42.51 & $11.17 \pm 1.64$ \\
\hline Chloroquine $5 \mathrm{mg} / \mathrm{kg}$ & $0.84 \pm 0.32^{\mathrm{d}}$ & 74.32 & $19.17 \pm 3.27^{\mathrm{c}}$ \\
\hline
\end{tabular}

Key: D7 = Day 7; Results are expressed as Mean \pm SEM $n=6$; One-way ANOVA, ${ }^{a} P<0.05^{b} p<0.01{ }^{c} p<0.001,{ }^{d} p<0.0001$ compared treatment to negative control

A decrease in the count of parasitized erythrocytes is widely used as an indicator of antiplasmodial activity of a test agent. The reduction in percentage parasitemia observed in this study is an indication of the plasmodial inhibitory potential of the pharmacologically active components of the preparations. The formulated syrup (S3) exhibited antiplasmodial activity indicating that formulation of the extract did not affect the actions of the active constituents. Although, chloroquine exhibited the highest parasite suppression $(74.32 \%)$, the results also show the propensity of the formulated syrup to reduce parasitemia by 28.44 and $42.51 \%$ at 200 and 400 $\mathrm{mg} / \mathrm{kg}$ respectively. This suggests its potential as an anti-malarial formulation and is consistent with reports from other studies [7, 24].

The presence of alkaloids, saponins, flavonoids, cardiac glycosides and tannins in Nauclea latifolia, may be responsible for its antimalarial activity [9] and this is observed to be exhibited in the syrup formulation. The mean survival time of the treated mice increased with dose but was shorter than the time observed in mice treated with the standard (chloroquine).

Malaria related anemia occurs in infections with the plasmodium parasite often causing alterations in blood cell parameters. Hematological analysis carried out on mice with established infections show decreased counts of blood cells that include red blood cells (RBC), hemoglobin (Hb), hematocrit (HCT) and platelet (Plt) count. Low blood cell count is associated with high parasite density caused by increased hemolysis and decreased rate of erythrocyte production [25].

Table 5: Effect of syrups containing AREL on hematological parameters in mice infected with Plasmodium berghei

\begin{tabular}{|r|r|r|r|r|}
\hline Treatment & Red Blood Cells (x10/L) & Hemoglobin (g/L) & Hematocrit (\%) & Platelet \\
\hline Control SV & $3.73 \pm 0.42$ & $162.33 \pm 8.65$ & $17.65 \pm 2.06$ & $126.30 \pm 34.31$ \\
\hline S3 $200 \mathrm{mg} / \mathrm{kg}$ & $4.45 \pm 0.63$ & $170.60 \pm 9.35$ & $20.57 \pm 2.86$ & $249.2 \pm 13.46$ \\
\hline S3 400 mg/kg & $5.26 \pm 0.78$ & $221.80 \pm 8.49$ & $30.73 \pm 2.34^{\mathrm{a}}$ & $227.0 \pm 41.42$ \\
\hline Chloroquine 5 mg/kg & $6.75 \pm 0.46^{\mathrm{a}}$ & $222.33 \pm 10.64^{\mathrm{a}}$ & $30.87 \pm 2.30^{\mathrm{a}}$ & $411.3 \pm 38.65^{\mathrm{b}}$ \\
\hline Sham & $16.52 \pm 2.69^{\mathrm{d}}$ & $376.60 \pm 18.67^{\mathrm{d}}$ & $58.66 \pm 2.60^{\mathrm{d}}$ & $1007 \pm 30.81^{\mathrm{d}}$ \\
\hline
\end{tabular}

Key: D7 = Day 7; Results are expressed as Mean \pm SEM $n=6$; One-way ANOVA, ${ }^{a} P<0.05^{b} p<0.01^{c} p<0.001,{ }^{d} p<0.0001$ compared treatment to negative control 
Administration of the syrup (S3), showed increasing levels of blood parameters as displayed in Table (5) which were comparable with that of chloroquine. This effect may be attributed to decreasing parasite density as the treatment was administered and also hematoprotective property of Nauclea latifolia which has earlier been reported [26].

\section{CONCLUSION}

This study shows that the dried aqueous root extract of Nauclea latifolia can be developed into syrup formulations with acceptable physicochemical properties using the combination of simple syrup and water as the most suitable vehicle. In vivo studies show that formulation of the extract into syrups did not alter its parasite-inhibitory properties.

Conflict of Interest: The authors declare no conflict of interest.

\section{ACKNOWLEDGEMENT}

The authors are grateful to the technical staff of the Department of Pharmaceutical Technology and Raw Materials Development and Solomon A. Fidelis and Leonard Nweze of the Department of Pharmacology and Toxicology, National Institute for Pharmaceutical Research and Development (NIPRD).

\section{REFERENCES}

1. World Health Organization (WHO). (2010). World Malaria Report 2010. Roll Back Malaria Partnership, New York. 6.

2. Salako, L. A., Ajayi, F. O., Sowunmi, A., \& Walker, O. (1990). Malaria in Nigeria: a revisit. Annual Tropical Medical Parasitolology. 84, 435445.

3. Abdulelah, H., Zurainee, M., Hesham, M., \& Rohela, M. (2010). Median Lethal Dose, Antimalarial Activity, Phytochemical Screening and Radical Scavenging of Methanolic Languas galangal Rhizome Extract. Molecules, 15, 83668376.

4. Bodeker, C., Bodeker, G., Ong, C. K., Grundy, C. K., Burford, G., \& Shein, K. (2005). WHO Global Atlas of Traditional, Complementary and Alternative Medicine. Geneva, Switzerland: World Health Organization.

5. Sofowora, H. (1993). Screening Plants for Bioactive Agents In: Medicinal Plants and Traditional Medicine in Africa, Spectrum Books Ltd., Sunshine House, Ibadan, Nigeria, 2nd Ed., 134156.

6. Karalliedde, L., \& Gawarammana, I. (2008) Traditional Herbal Medicines. A guide to safer use of herbal medicines. Hammersmith Press, London. 978-1-905140-04-6.

7. Ameh, S., Obodozie, O., Gamaniel, S., Abubakar, M., \& Garba, M. (2010). Physicochemical variables and real time stability of the herbal substance of Niprd-AM1®- an antimalarial developed from the root of Nauclea latifolia S.M. (Rubiaceae). International Journal of Phytomedicine. 2, 332-340.

8. Abdulelah, H., Zurainee, M., Hesham, M., \& Rohela, M. (2010). Median Lethal Dose, Antimalarial Activity, Phytochemical Screening and Radical Scavenging of Methanolic Languas galangal Rhizome Extract. Molecules. 15, 83668376.

9. Ettebong, E. O., Edwin, U. P. M., Edet, E., Ekong, U. S., Akpan, O. E., \& Tambari, V. D. (2015). In vivo antiplasmodial activities of Nauclea latifolia. Asian Journal of Medical Sciences. 6(3), 1- 11.

10. Anowi, C., Chibueze, I., Ezeokafor, E., \& Anikpe, N. (2015). Investigation into the anti-malarial activity of the aqueous leaf extract of Nauclea latifolia (Rubiaceae) using curative method. Journal of Pharmacognosy and Phytochemistry. 4(4), 68-71.

11. Bidla, G., Titanji, V. K. P., Joko, B., El-Ghazali, G., Bolad, A., \& Berzins, K. (2004). Antiplasmodial activity of seven plants used in African folk medicine. Indian Journal of Pharmacology. 38, 245-260.

12. Katsayal, U., \& Obamiro, K. (2007). In vivo antiplasmodial activity and phytochemical screening of ethanolic extract of the leaves of Cissampelos mucronata. Nigerian Journal of Pharmaceutical Science. 6(2), 111-115.

13. Builders, M., Wannang, N., \& Aguiyi, J. (2011). Antiplasmodial activities of Parkia biglobosa leaves: In vivo and In vitro studies. Annals of Biological Research. 2(4), 8-20.

14. Jeruto, P., Nyangacha, R., \& Mutai, C. (2015). In vitro and In vivo antiplasmodial activity of extracts of selected Kenyan medicinal plants. African Journal of Pharmacy and Pharmacology. 9(16), 500-505.

15. Innocent, A., Aniekan, I., \& Aquaisua, N. (2017). Histopathological effect of $N$. latifolia Ethanolic Leaf Extract and Artemeter/Lumefantrine on the Hippocampus of $P$. berghei Infected Mice. International Journal of Brain and Cognitive Science. 6(1), 9-16.

16. Anu, K., Vivek, C., \& Sudha, D. (2016) Formulation and evaluation of herbal cough syrup. European Journal of Pharmaceutical and Medical Research. 3(5), 517-522.

17. Ryley, J. F., \& Peters, W. (1970). The antimalarial activity of some quinoline esters. Annals of Tropical medicine and Parasitology. 64, 209-222.

18. Iwu, M., Duncan, A., \& Okunji C. (1999). New antimicrobials of plant origin. In J. Janick (Ed.), Perspectives on new crops and new uses (pp. 457462). Alexandria, Virginia, U.S.A: ASHS Press.

19. Maga, J. A. (1990). Compound structure versus bitter taste. In: Rousseff RL, ed. Bitterness in 
foods and beverages; developments in food science 25. Amsterdam: Elsevier: 35-48.

20. Lusby, P. E., Coombes, A. L., \& Wilkinson, J. M. (2005). Bactericidal activity of different honeys against pathogenic bacteria. Archive of Medical Research. 36, 464-467.

21. Nwabuisi, C. (2002). Prophylactic effect of multiherbal extract Agbo-Iba on malariainduced in mice. East African Medical Journal. 79, 343-346.

22. Mukubwa, G. K., Nkanga, C. I., Buya, A. B., Mbinze, J. K., Krause. R. W. M., \& Memvanga, P. B. (2020). Self-nanoemulsifying drug delivery systems (SNEDDS) for oral delivery of Garcinia kola seeds ethanolic extract: (formulation and in vivo antimalarial activity). Journal of Pharmacy and Pharmacognosy Research. 8(3), 177-190.

23. Udobre, A. S., Udoabang, J. A., Udoh, A. E., Anah, V. U., Akpan, A. E., \& Charles, G. E. (2013). Effect of methanol leaf extract of Nauclea latifolia on albino mice infected with Plasmodium berghei. Africa Journal of Pharmacology and Therapeutics. 2(3), 83-87.

24. Asanga, E. E., Eseyin, O., Ebong, P., Igile, G., Thomas, P. S., \& Ebong, A. (2017). Antiplasmodial activity of ethanol extract and fractions of Nauclea Latifolia Smith (Rubiacea) roots. World Journal of Pharmaceutical Sciences. 5(5), 106-118.

25. Kotepui, M., Piwkham, D., PhunPhech, B., Phiwklam, N., Chupeerach, C., \& Duangmano, S. (2015). Effects of malaria parasite density on blood cell parameters. PLoS One. 10(3).

26. Edet, A. E., Patrick, E. E., \& Olorunfemi, E. A. (2013). Hematological parameters of alloxan induced diabetic rats treated with ethanol extract and fractions of Nauclea latifolia. European Scientific Journal. 9(27):203-210.

27. Kumar, V., Dixon, D., Tewari, D., \& Wadgaonkar, D. B. (2014). U.S. Patent No. 8,637,540. Washington, DC: U.S. Patent and Trademark Office. 